\title{
Diversity and seasonal dynamics of the photoautotrophic picoplankton in Lake Balaton (Hungary)
}

\author{
Tamás Felföldii ${ }^{1 *}$, Mónika Duleba ${ }^{1}$, Boglárka Somogyi ${ }^{2}$, Balázs Vajna ${ }^{1}$, \\ Marcell Nikolausz ${ }^{1,3}$, Mátyás Présing ${ }^{2}$, Károly Márialigetii ${ }^{1}$, Lajos Vörös ${ }^{2}$ \\ ${ }^{1}$ Department of Microbiology, Eötvös Loránd University, Pázmány Péter stny. 1/c., 1117 Budapest, Hungary \\ ${ }^{2}$ Balaton Limnological Institute of the Hungarian Academy of Sciences, Klebelsberg Kuno u. 3., 8237 Tihany, Hungary \\ ${ }^{3}$ Present address: Department of Bioenergy, Helmholtz Centre for Environmental Research - UFZ, Torgauer Str. 116, \\ 04347 Leipzig, Germany
}

\begin{abstract}
Lake Balaton, in Hungary, is the largest shallow lake in Central Europe. This freshwater ecosystem has been well studied, including investigations of its photoautotrophic picoplankton (PPP). Previous studies revealed that picoeukaryotes could reach an extremely high abundance in winter, while picocyanobacteria are the predominant picoplankters in warmer periods, as in other lakes in the temperate zone. In addition to epifluorescence microscopy - which allows discrimination only between phycocyanin-rich picocyanobacteria, phycoerythrin-rich picocyanobacteria and picoeukaryotic algae - we used PCR-based molecular methods to reveal the detailed genetic diversity and seasonal dynamics of the PPP in Lake Balaton for the first time. Our results show that a single integrated pelagic sample, taken vertically from the whole water column, may harbor a large number of picocyanobacterial genotypes including previously unidentified groups. Based on length polymorphism analysis of the phycocyanin operon (which contains a non-coding region of variable size), the composition of picocyanobacterial communities showed significant seasonal changes and spatial variation. The relative importance of some of the operational taxonomic units (OTUs) we detected was correlated with environmental factors, such as temperature and the concentration of available nitrogen forms. The picoeukaryotic algal community of winter PPP was dominated by chlorophytes related to the group Trebouxiophyceae. The results of this study highlight the fine internal structure and dynamics of the PPP community in freshwater ecosystems - a view that is usually blurred by the lower resolution of commonly used methods, such as epifluorescence microscopy and flow cytometry.
\end{abstract}

KEY WORDS: Photoautotrophic picoplankton · 16S rRNA gene - Phycocyanin operon · Length polymorphism · Lake Balaton

\section{INTRODUCTION}

The meso-eutrophic Lake Balaton, in Hungary, is the largest shallow lake in Central Europe. In the last few decades, the abundance and composition of the photoautotrophic picoplankton (PPP) community in this lake - which contributes up to $50 \%$ of the planktonic primary production - have been intensively studied with epifluorescence microscopy (Vörös 1991, Vörös et al. 1998, Mózes et al. 2006, Vörös et al. 2009). This technique distinguishes 3 major forms of freshwater PPP: phycocyanin (PC)-rich picocyanobacteria, phycoerythrin (PE)-rich picocyanobacteria and picoeukaryotic algae (MacIsaac \& Stockner 1993). The latter group is predominant in the winter picoplankton of the lake, sometimes with only a negligible abundance of picocyanobacteria. On the other hand, picocyanobacteria were found in high numbers in the warmer periods (Mózes et al. 2006, Vörös et al. 2009). As in other lakes in the temperate zone, the PPP has a 
bimodal distribution, with biomass peaks in the spring (May) and in the fall (September to October) (Vörös 1991, Vörös et al. 1991). The population decline in summer was concomitant with the mass development of filamentous nitrogen-fixing cyanobacteria (Vörös et al. 1991) and the shift in the PPP from single-celled to colonial forms (Mózes et al. 2006). Regarding their spatial distribution, PE-rich picocyanobacteria dominated the eastern, mesotrophic basin, while PC-rich forms prevailed in the western, eutrophic part. This specific distribution pattern was due to the different spectral composition of the underwater light in the 2 basins (Vörös et al. 1998, Stomp et al. 2007). These investigations also revealed the inverse relationship between the contribution of PPP to total phytoplankton biomass and trophic state (Mózes et al. 2006, Vörös et al. 2009), in accordance with previous studies (Pick 1991, Agawin et al. 2000, Bell \& Kalff 2001).

Tracking spatial and temporal changes in the taxonomic composition of the PPP communities is not possible with classical methods (such as microscopy) because of the lack of morphological features that can be used to distinguish between distantly related taxa. By contrast, PCR-based molecular methods provide adequate tools for the taxonomic definition of PPP communities and isolates. A high genetic diversity among the members of freshwater picoplankton was revealed by earlier investigations (Crosbie et al. 2003a, Becker et al. 2004, 2007, Ivanikova et al. 2007, Felföldi et al. 2009, Somogyi et al. 2010), but studies dealing with the seasonal changes of individual picocyanobacterial genotypes in freshwater habitats are relatively scarce.

Analyzing 4 aerobic epilimnion samples of the small, stratified sulfide-rich Lake Vilar (Spain), Casamayor et al. (2002) found that the relative importance of 2 Synechococcus genotypes changed between February and June. Becker et al. $(2002,2004,2007)$ followed the abundance of a PE-rich and a PC-rich Synechococcus genotype seasonally in Lake Constance (Central Europe); these studies revealed the internal dynamics of picocyanobacteria in the pelagic zone. Ivanikova et al. (2007) found differences in the ratios of different picocyanobacterial genotypes in 3 offshore stations when they compared samples taken from Lake Superior in May and September. Sánchez-Baracaldo et al. (2008) have followed the quantitave changes of 4 picocyanobacterial clades in 2 manmade lakes in the UK over an annual cycle. Finally, in our previous study (Felföldi et al. 2009), we observed temporal shifts in the genetic composition of the PPP community in several turbid alkaline pans of the Carpathian Basin (Central Europe).

The aims of this study were (1) to characterize the genetic diversity of the PPP in Lake Balaton, (2) to reveal the seasonal dynamics of picocyanobacterial genotypes, and (3) to study the relationships between the relative abundance of some selected genotypes and biotic and abiotic environmental conditions. Our results give insight into the structure of the PPP community in a temperate shallow lake, including some aspects of the internal dynamics of these organisms.

\section{MATERIALS AND METHODS}

Study site, sample collection and characterization. The surface area of Lake Balaton is $596 \mathrm{~km}^{2}$, and the average depth is $3.25 \mathrm{~m}$. The dominant ions in the lake water are $\mathrm{Ca}^{2+}, \mathrm{Mg}^{2+}$ and $\mathrm{HCO}_{3}{ }^{-}$, and the typical $\mathrm{pH}$ and conductivity values are 8.3 to 8.6 and 600 to $700 \mu \mathrm{S}$ $\mathrm{Cm}^{-1}$, respectively (Herodek 1988). The geographic location of Lake Balaton and the positions of sampling sites are presented in Fig. 1. Integrated pelagic samples (i.e. vertical samples from the whole water column) were collected with a 51 tube sampler fortnightly, from 24 April to 4 September 2006, in the eastern, mesotrophic Siófok Basin (Tihany sampling station) and in the western, eutrophic part of the lake, the Keszthely Basin (Keszthely sampling station). Two additional samples from the latter basin (taken on 19 February 2003 and 26 October 2005) were also processed for a more detailed analysis by cloning and sequencing. Temperature, $\mathrm{pH}$ and conductivity values were determined for each sample with a WTW MultiLine P-4

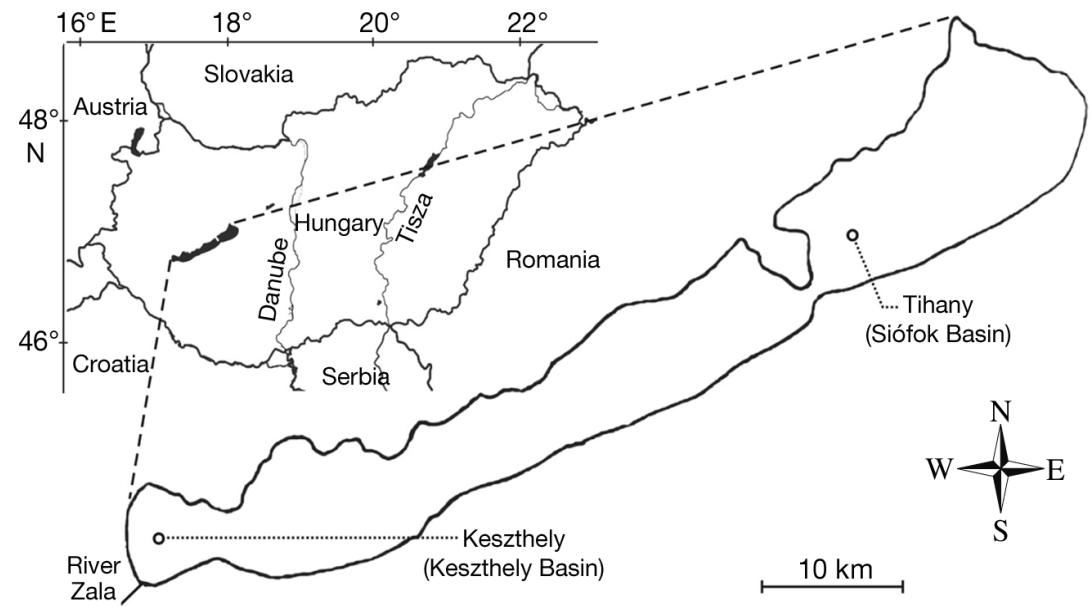

Fig. 1. Sampling sites. Sampling stations are indicated with open circles, and the basins of Lake Balaton (Hungary) are shown in parentheses. Scale bar pertains to the enlarged map of the lake 
meter. Photosynthetically active radiation (PAR) in the water column was measured with a Li-COR underwater radiometer, using a flat $(2 \pi)$ quantum sensor. Concentrations of $\mathrm{NH}_{4}{ }^{+}-\mathrm{N}, \mathrm{NO}_{3}{ }^{-}-\mathrm{N}$ and urea-N were determined as described in Présing et al. (2001). The concentration of chlorophyll a ( $\mathrm{chl}$ a) was measured spectrophotometrically according to Wetzel \& Likens (1991). The PPP was determined from fresh samples, while nanoplankton and microplankton were studied from Lugol-preserved samples. The abundance of picocyanobacteria and picoeukaryotes (cells $\leq 2 \mu \mathrm{m}$ ) was determined with epifluorescence microscopy (Nikon Optiphot 2) according to MacIsaac \& Stockner (1993). Species identification and the enumeration of larger cyanobacteria were performed on an inverted microscope using the Utermöhl technique (Utermöhl 1958). The dimensions of at least 10 individuals were measured for each species. Cell volumes were calculated on the basis of cell geometry (Hillebrand et al. 1999). The wet weight (biomass) of individual species was estimated assuming a specific gravity of 1.0.

Origin of picocyanobacterial isolates. Eight picocyanobacterial isolates (ACT 9701, ACT 9711, ACT 9801, ACT 9802, ACT 9803, ACT 9804, ACT 9806 and ACT 9807) were obtained from the Algal Collection of the Balaton Limnological Research Institute (Tihany, Hungary). All strains were isolated from Lake Balaton between 1996 and 1998. The cultures were maintained in a modified BG-11 medium in which only one tenth of the recommended micronutrient solution was used (Rippka et al. 1979), at $21^{\circ} \mathrm{C}, 60 \mu \mathrm{mol} \mathrm{m}{ }^{-2} \mathrm{~s}^{-1}$ light intensity and $14 \mathrm{~h}$ light:10 h dark cycle.

DNA extraction. Genomic DNA was extracted from picocyanobacterial isolates and from phytoplankton samples according to the following protocol. After concentration of 200 to $300 \mathrm{ml}$ of sample water by filtration, cells were disrupted in liquid nitrogen by grinding, followed by the addition of $1 \mathrm{ml}$ CLS-Y cell lysis solution (Bio101 Systems, Q-Biogene) and approximately $5 \mathrm{mg}$ of polyvinyl-polypyrrolidone. After centrifugation $(15000 \times g, 5 \mathrm{~min})$, the supernatant containing the genomic DNA was purified with the G-Spin ${ }^{\mathrm{TM}}$ Genomic DNA Extraction Kit (Intron Biotechnology) according to the manufacturer's protocol.

PCR amplification. PCRs were performed with a final volume of $50 \mu \mathrm{l}$ using 0.5 to $4 \mu \mathrm{l}$ of purified genomic DNA, $0.2 \mathrm{mM}$ of each deoxynucleotide, $2 \mathrm{mM}$ $\mathrm{MgCl}_{2}, 1 \mathrm{U}$ LC Taq DNA polymerase (Fermentas), 1× PCR buffer (Fermentas) and $0.325 \mu \mathrm{M}$ of both primers. In separate reactions we used: 16S rRNA genetargeted, cyanobacteria-specific and chloroplast-specific primers (CYA106F and CYA781R, Nübel et al. 1997), and phycocyanin operon ( $с p c B A$-intergenic spacer [IGS])-targeted, Synechococcus-specific primers (cpcBF[UFP] and cpcAR[URP], Robertson et al.
2001). The following temperature profile was used for the 16S rRNA gene: initial denaturation at $98^{\circ} \mathrm{C}$ for $5 \mathrm{~min}$, followed by 32 cycles of $30 \mathrm{~s}$ at $94^{\circ} \mathrm{C}$ (denaturation), $30 \mathrm{~s}$ at $60^{\circ} \mathrm{C}$ (annealing), $1 \mathrm{~min}$ at $72^{\circ} \mathrm{C}$ (extension), and a final extension at $72^{\circ} \mathrm{C}$ for $10 \mathrm{~min}$ (or 30 min for cloning). The temperature profile for $c p c B A$ IGS was: initial denaturation at $98^{\circ} \mathrm{C}$ for $5 \mathrm{~min}$, followed by 32 cycles of $45 \mathrm{~s}$ at $94^{\circ} \mathrm{C}$ (denaturation), $45 \mathrm{~s}$ at $45^{\circ} \mathrm{C}$ (annealing), $45 \mathrm{~s}$ at $72^{\circ} \mathrm{C}$ (extension), and a final extension at $72^{\circ} \mathrm{C}$ for $10 \mathrm{~min}$ (or $30 \mathrm{~min}$ for cloning). PCR amplicons were examined by electrophoresis in an ethidium-bromide-stained 1\% (w/v) agarose gel under UV light.

Construction of clone libraries, sequence analysis and phylogenetic reconstruction. Clone library construction, restriction analysis of clones and sequencing were performed according to Felföldi et al. (2009). Phylogenetic analysis was perfomed with the MEGA4 software (Tamura et al. 2007) using the neighbor-joining method. Evolutionary distances were computed using the Kimura 2-parameter nucleotide substitution method, and the bootstrap test was conducted with 1000 replicates.

Clone codes were generated from the following abbreviations: 'Ke', the western Keszthely Basin (referring to Keszthely town, close to the sampling site) and 'Ti', the eastern Siófok Basin of Lake Balaton (referring to Tihany village, close to the sampling site); '0219' (winter), '0424' (spring), '0904' (early fall) and '1026' (late fall) refer to sampling dates (note that, in these numbers, the month is given first - e.g. ' 0219 ' refers to 19 February); ' $\mathrm{r}$ ' and ' $\mathrm{c}$ ' for the 16S rRNA gene and cpcBA-IGS region clones, respectively; the number at the end of the code is a serial number.

Determination of almost full-length 16S rRNA gene sequences of isolates. After a phylogenetic reconstruction based on partial 16S rRNA gene sequences, almost full-length 16S rRNA gene sequences were determined for major Synechococcus genotypes (namely, for ACT 9802 and ACT 9807). PCR amplification was performed with the primers $27 \mathrm{~F}$ and $1492 \mathrm{R}$ (Lane 1991) followed by sequence analysis using primers 27F, CYA106F, 338F (Lane 1991), CYA781R, and $1492 \mathrm{R}$. If direct sequencing with these primers was not possible (due to the presence of heterotrophic bacteria in the unicyanobacterial cultures), a small clone library was generated. Clones were screened by partial sequencing of the inserts, and then the complete sequence of the selected clone containing the picocyanobacterial insert was determined. Sequence assembly and phylogenetic analysis were performed using the MEGA4 software as described above.

Length polymorphism of the phycocyanin operon. The $c p c B A$-IGS region was amplified from environmental genomic DNA samples and from pico- 
cyanobacterial isolates as described above, except that the $\operatorname{cpcBF}$ (UFP) primer was fluorescently labeled at the 5' end. Two additional Synechococcus isolates (ACT 9808 and ACT 9809, both isolated from a fish pond in Hungary and belonging to phylogenetic Group $F$; Felföldi et al. 2011) were also involved to aim the identification of the amplicon length of unknown community members. Length heterogeneity PCR (LH-PCR) molecular fingerprints were generated by the capillary electrophoresis of labeled PCR products as reported in Sipos et al. (2007). Pattern analysis was carried out, as described by Vajna et al. (2010), by comparing the LHPCR patterns of the isolates (generated with $5^{\prime}$-TETlabeled cpcBF(UFP) primer) with the community fingerprints (generated with 5'-HEX-labeled cpcBF[UFP] primer). The relative abundance of operational taxonomic units (OTUs, corresponding to different peaks) was defined as the ratio of individual peak area to total peak area, excluding primer peaks.

Statistical analysis. The following environmental variables were included in the analysis: water temperature (T), concentration of $\mathrm{NH}_{4}{ }^{+}-\mathrm{N}, \mathrm{NO}_{3}{ }^{-}-\mathrm{N}$ and urea$\mathrm{N}_{i}$ sum of all measured nitrogen-forms $(\Sigma \mathrm{N})$; chl $a_{i}$ abundance of PC-rich picocyanobacteria (PC-PCy), PE-rich picocyanobacteria (PE-PCy), colonial picocyanobacteria (col-PCy), all picocyanobacteria ( $\mathrm{PPCy})$, and the biomass of non-PPP cyanobacteria (non-PPPCy). Environmental variables were standardized by range. Relationships between environmental variables and the relative abundance of LH-PCR OTUs were analyzed with correlation and principal component analysis (PCA) ordination combined with vector-fitting. Spearman correlation was performed with the PAST software (Hammer et al. 2001) using a multiple-

Table 1. Environmental variables in samples from 2 basins in Lake Balaton (Hungary), in the warm-water period of 2006. Average values are shown in parentheses. PC: phycocyanin; PE: phycoerythrin; PPP: photoautotrophic picoplankton

\begin{tabular}{|c|c|c|}
\hline Parameter & $\begin{array}{l}\text { Western basin } \\
\text { (Keszthely Basin) }\end{array}$ & $\begin{array}{l}\text { Eastern basin } \\
\text { (Siófok Basin) }\end{array}$ \\
\hline Water temperature $\left({ }^{\circ} \mathrm{C}\right)$ & $17.0-27.8(21.7)$ & $16.1-27.0(20.9)$ \\
\hline $\mathrm{pH}$ & $8.2-8.7(8.5)$ & $8.4-8.8(8.6)$ \\
\hline Conductivity $\left(\mu \mathrm{S} \mathrm{cm}^{-1}\right)$ & $666-772(731)$ & $778-805(788)$ \\
\hline $\mathrm{K}_{\mathrm{d}}\left(1 \mathrm{~m}^{-1}\right)$ & $1.6-3.4(2.3)$ & $0.7-2.1(1.2)$ \\
\hline $\mathrm{NH}_{4}^{+}-\mathrm{N}\left(\mu g \mathrm{l}^{-1}\right)$ & $4.4-10.5(7.1)$ & $3.7-22.2(9.9)$ \\
\hline $\mathrm{NO}_{3}{ }^{-}-\mathrm{N}\left(\mu \mathrm{g} \mathrm{l}^{-1}\right)$ & $0-27.0(10.5)$ & $5.8-37.8(15.5)$ \\
\hline Urea-N $\left(\mu \mathrm{g} \mathrm{l}^{-1}\right)$ & $6.2-55.3(20.1)$ & $12.3-52.5(30.8)$ \\
\hline Chl a $\left(\mu \mathrm{g} \mathrm{l}^{-1}\right)$ & $8.2-66.4(24.1)$ & $2.3-18.1(6.5)$ \\
\hline PC-rich picocyanobacteria $\left(10^{4}\right.$ cells $\left.\mathrm{ml}^{-1}\right)$ & $12.4-43.2(30.1)$ & $1.78-13.0(7.84)$ \\
\hline PE-rich picocyanobacteria $\left(10^{4}\right.$ cells $\left.\mathrm{ml}^{-1}\right)$ & $0.93-45.4(12.9)$ & $21.1-35.5(29.7)$ \\
\hline Colonial picocyanobacteria $\left(10^{4}\right.$ cells $\left.\mathrm{ml}^{-1}\right)$ & $8.07-37.4(22.5)$ & $4.19-34.1(17.9)$ \\
\hline All picocyanobacteria $\left(10^{4}\right.$ cells ml $\left.^{-1}\right)$ & $24.9-57.7(43.0)$ & $27.0-44.5(37.5)$ \\
\hline Non-PPP cyanobacteria $\left(\mu \mathrm{g} \mathrm{l}^{-1}\right)$ & $85-8496(2675)$ & $10-162(97)$ \\
\hline
\end{tabular}

comparison correction (Bonferroni) for the p values $\left(p^{\prime}\right)$. The OTUs were fitted as vectors with 'envfit' function (package vegan) onto the PCA ordination of environmental variables and the significance of fittings was tested with random permutations in program $\mathrm{R}$ (Oksanen et al. 2010, R Development Core Team 2010).

Nucleotide sequence accession numbers. GenBank accession numbers of the nucleotide sequences determined in this study are: GQ422900 to GQ422959 for 16S rRNA gene sequences and GQ888536 to GQ888576 for $c p c B A$-IGS sequences.

\section{RESULTS}

\section{Environmental variables, photoautotrophic picoplankton and larger cyanobacteria}

Water temperature and $\mathrm{pH}$ had the same values in the 2 basins of the lake in the warm-water period of 2006, while the conductivity was somewhat higher in the mesotrophic eastern basin (Table 1). Average values of $K_{d}$ (vertical extinction coefficient) and chl a content were higher in the western basin, while the eastern basin was characterized by slightly higher values of measured nitrogen forms. The abundance of single-celled and colonial picocyanobacteria was slightly higher in the western basin than in the eastern basin. The western site was characterized by the dominance of PC-rich forms, while the eastern site was characterized by the dominance of PE-rich picocyanobacteria (Fig. 2A). Picoeukaryotic algae were almost negligible in the warm-water period of 2006, but their abundance was high $\left(28.8 \times 10^{4}\right.$ cells $\mathrm{ml}^{-1}$ ) in February 2003 (Table 2). Based on identification by microscopy, nonPPP cyanobacteria in this period were Anabaena aphanizomenoides Forti, Anabaena spiroides Klebahn, Aphanizomenon gracile Lemmermann, Aphanizomenon issatschenkoi (Ussaczew) Proshkina-Lavrenko, Cylindrospermopsis raciborskii (Woloszynska) Seenayya \& Subba Raju, Planktolyngbya circumcreta (West) Anagnostidis \& Komárek, Planktolyngbia limnetica (Lemmermann) Komárková-Legnerová \& Cronberg, Planktothrix agardhii (Gomont) Anagnostidis \& Komárek and Snowella lacustris (Chodat) Komárek \& Hindák in the western basin, and A. gracile, P. limnetica, $P$. circumcreta, Microcystis flos-aquae (Wittrock) Kirchner and S. lacustris in the eastern basin (Fig. 2C). 


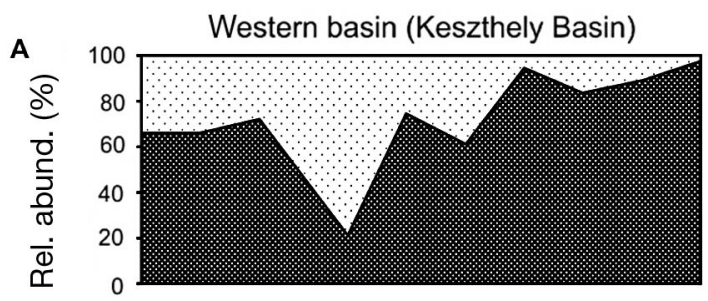

PE-rich picocyanobacteria

PC-rich picocyanobacteria
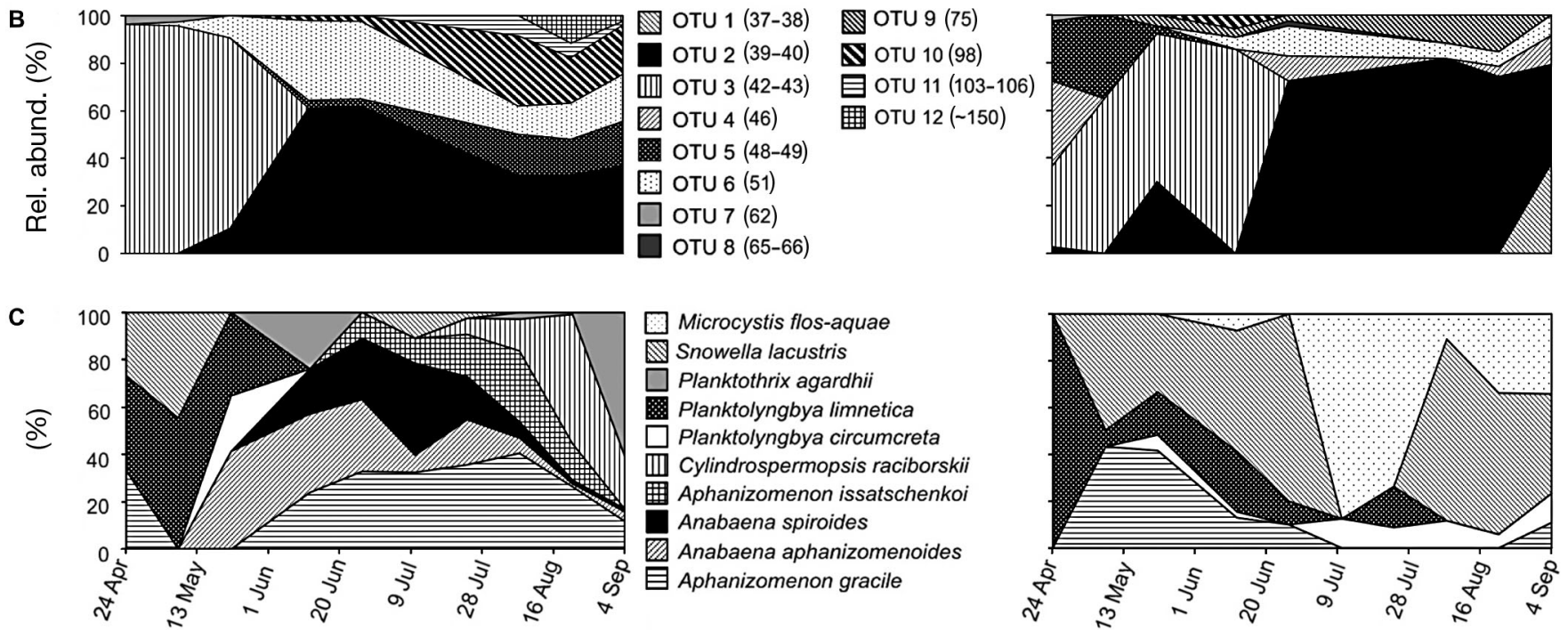

Fig. 2. Temporal changes in the composition of the cyanobacterial communities in 2 different basins of Lake Balaton (Hungary) during the warm-water period of 2006. (A) Composition of picocyanobacteria based on epifluorescence microscopy (relative abundance [rel. abund.] calculated from cell density). (B) Composition of the picocyanobacterial community based on length heterogeneity PCR (LH-PCR) (relative abundance of operational taxonomic units [OTUs]; the characteristic IGS length of each OTU is shown in parentheses). (C) Composition of larger (non-PPP) cyanobacteria based on light microscopy (relative importance calculated from biomass). PE: phycoerythrin; PC: phycocyanin

\section{Picocyanobacterial strains}

Picocyanobacterial strains were characterized by partial sequences of the 16S rRNA gene and the phycocyanin operon ( the phylogenetic analysis of both regions, the only PE- rich strain, ACT 9807 (synonym: NIVA CYA 375), clustered with Group B (Robertson et al. 2001), also known as subalpine cluster I (Ernst et al. 2003). The other 7 strains were affiliated with Group A picocyanobacteria (Cyanobium gracile cluster), sharing $100 \%$ pairwise similarities of the $16 \mathrm{~S}$ rRNA gene, and were identical

Table 2. Environmental variables in the samples used for cloning and sequencing. PC: phycocyanin; PE: phycoerythrin; nd: no data

\begin{tabular}{|c|c|c|c|c|}
\hline Parameter & $\begin{array}{c}19 \text { Feb } 2003 \\
\text { Western basin }\end{array}$ & $\begin{array}{c}26 \text { Oct } 2005 \\
\text { Western basin }\end{array}$ & $\begin{array}{l}24 \text { Apr } 2006 \\
\text { Eastern basin }\end{array}$ & $\begin{array}{c}4 \text { Sep } 2006 \\
\text { Eastern basin }\end{array}$ \\
\hline Investigated genomic region & 16S rRNA gene & 16S rRNA gene & срсBA-IGS & срсBA-IGS \\
\hline Water temperature $\left({ }^{\circ} \mathrm{C}\right)$ & 0.8 & 12.2 & 17.2 & 20.1 \\
\hline $\mathrm{pH}$ & 8.4 & 8.1 & 8.5 & 8.3 \\
\hline Conductivity $\left(\mu \mathrm{S} \mathrm{cm}^{-1}\right)$ & 800 & 727 & 781 & 691 \\
\hline $\mathrm{K}_{\mathrm{d}}\left(1 \mathrm{~m}^{-1}\right)$ & 1.6 & 1.8 & 1.2 & 1.9 \\
\hline Chl a $\left(\mu \mathrm{gl}^{-1}\right)$ & 11.0 & 10.7 & 5.86 & 33.7 \\
\hline PC-rich picocyanobacteria $\left(10^{4}\right.$ cells $\left.\mathrm{ml}^{-1}\right)$ & nd & 19.6 & 7.75 & 35.6 \\
\hline PE-rich picocyanobacteria $\left(10^{4}\right.$ cells $\left.\mathrm{ml}^{-1}\right)$ & nd & 13.1 & 26.6 & 0.93 \\
\hline Colonial picocyanobacteria $\left(10^{4}\right.$ cells $\left.\mathrm{ml}^{-1}\right)$ & nd & 0.97 & 4.19 & 10.4 \\
\hline All picocyanobacteria $\left(10^{4}\right.$ cells $\left.\mathrm{ml}^{-1}\right)$ & 1.4 & 32.7 & 34.4 & 36.6 \\
\hline Picoeukaryotic algae $\left(10^{4} \mathrm{cells} \mathrm{ml}^{-1}\right)$ & 28.8 & $<0.1$ & $<0.1$ & $<0.1$ \\
\hline
\end{tabular}




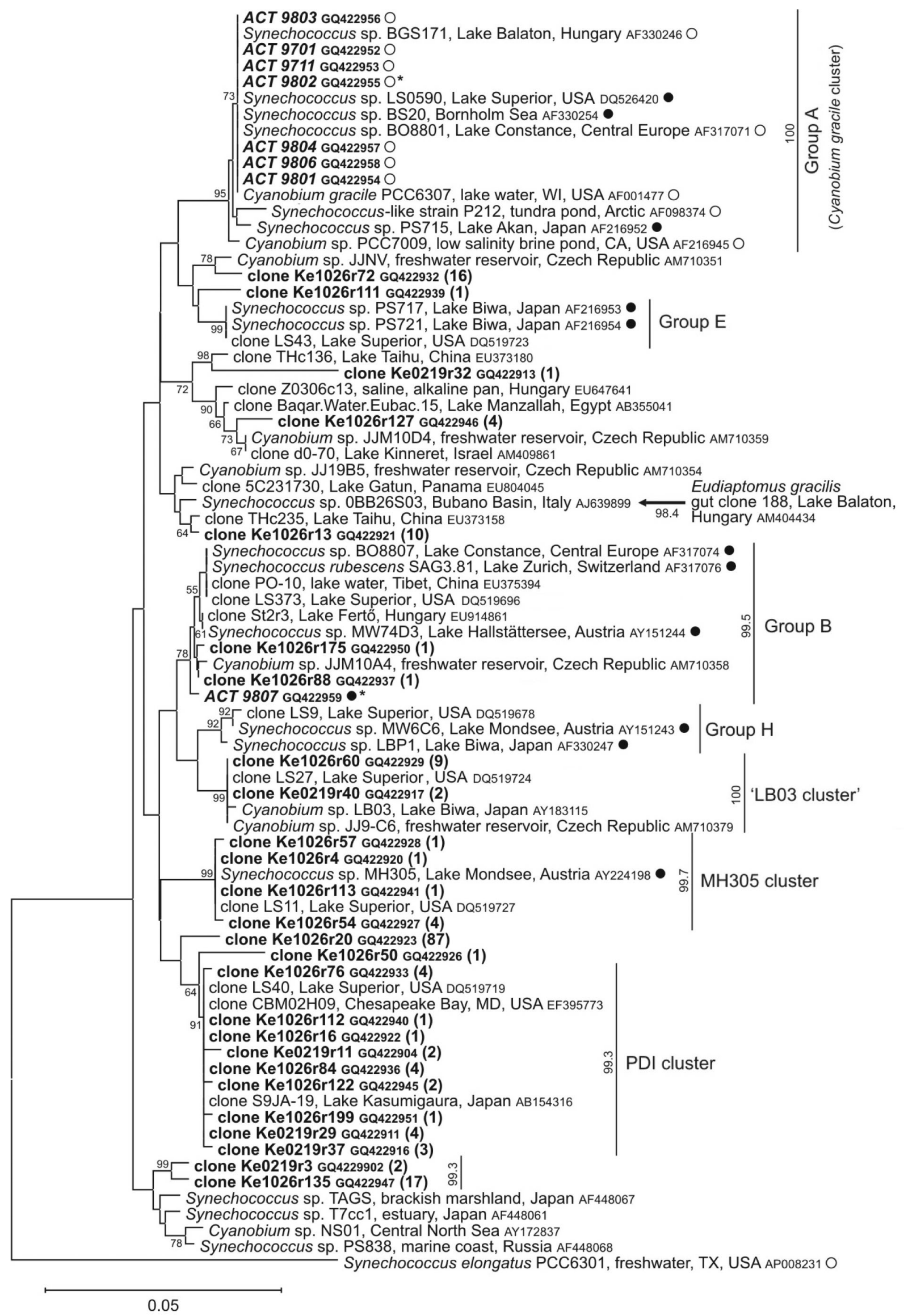


Fig. 3. Phylogenetic position of picocyanobacterial isolates and 16S rRNA-gene-derived clones from Lake Balaton (Hungary) inside the picophytoplankton clade of Cyanobacteria. The neighbor-joining tree is based on 542 unambiguously aligned nucleotide positions. Bootstrap values higher than $50 \%$ are shown. Pigment group ( phycoerythrin [PE]-rich, $\mathrm{O}$ phycocyanin [PC]-rich) and isolation details are also shown. Sequences determined in this study appear in bold (clones) and bold italics (isolates). The number of clones affiliated to each sequence is given in parentheses. Isolates investigated in this study with almost full-length 16S rRNA gene sequences are marked with an asterisk $\left({ }^{*}\right)$. Cluster designations are according to Robertson et al. (2001), Crosbie et al. (2003a), Ernst et al. (2003) and Ivanikova et al. (2007). Minimum pairwise similarities of sequences determined herein are shown for each group. Synechococcus elongatus PCC6301 was used as outgroup. The approximate phylogenetic position of AM404434 is shown by an arrow with the pairwise sequence similarity value (this sequence corresponds to a shorter and upstream region within the 16S rRNA gene compared with the others determined in this study)

to Synechococcus sp. BGS171, the only picocyanobacterial strain from Lake Balaton that was characterized previously by molecular biological methods (Ernst et al. 2003). These isolates showed 97.4 to $100 \%$ pairwise similarities to each other based on the $с p c B A-I G S$ region.

Similar results were found by analyzing the almost full-length 16S rRNA gene sequences of strains ACT 9802 and ACT 9807 (GenBank accession numbers: GQ422955 and GQ422959, data not shown).

\section{Genetic diversity of picocyanobacteria}

The 16S rRNA gene and $c p c B A$-IGS sequence are the most widely used phylogenetic markers in diversity studies of freshwater picocyanobacteria (e.g. Robertson et al. 2001, Crosbie et al. 2003a, Ivanikova et al. 2007, Somogyi et al. 2010). Lake Balaton is one of the most intensively investigated freshwater lakes regarding the PPP (e.g. Mózes et al. 2006, Vörös et al. 2009), but there is a lack of information about the genetic diversity of this group. Therefore, cloning and sequencing were performed to assess the genetic composition of this group - applying both genes and covering different seasons. Thus, we used a winter sample (19 February 2003) from the western basin with an extraordinarily high number of picoeukaryotic cells; a late fall sample (26 October 2005) and an early fall sample (4 September 2006) from the same site; and a spring sample (24 April 2006) from the eastern basin (Table 2). The choice of samples for constructing the срсBA-IGS clone library was also influenced by the results of the LH-PCR analysis (see later, Fig. 2B).

The majority of cyanobacterial sequences determined in the clone libraries originating from Lake Balaton (corresponding to 73 to $93 \%$ of the total number of clones) were related to the picophytoplankton clade of Cyanobacteria sensu Urbach et al. (1998) (Figs. 3 \& 4). Members of 2 clusters (Group B and the MH305 cluster) were presented simultaneously among the clones based on the 2 different genomic regions. Ten additional groups were detected based on both the $16 \mathrm{~S}$
rRNA gene and the $с p c B A$-IGS region. A significant number of clones were only distantly related to sequences available from GenBank, representing previously unknown genotypes, and therefore probably unknown picocyanobacteria. Members of Group A, which contained the majority of Lake Balaton isolates, were not found among the clones derived from samples taken in February, September and October. The only uncultured member (clone Ti0424c30) was retrieved from the clone library constructed from the sample taken in April. The picocyanobacterial genotype that was retrieved from the gut of Eudiaptomus gracilis (Crustacea, Copepoda) from Lake Balaton (Homonnay et al. 2011; Fig. 3) was distantly related to the groups detected in this study.

Combining the results of isolates and clones, at least 12 different groups of picocyanobacteria were detected within the picophytoplankton clade in Lake Balaton.

\section{Genetic diversity of other algae}

The molecular investigation of both regions (the $16 \mathrm{~S}$ rRNA gene and the $c p c B A$-IGS sequence) confirmed the presence of several other common oxygenic phototrophs in the lake, including freshwater genera such as Planktothrix, Microcystis, Snowella, Anabaena, Dinophysis etc. (Figs. 4 \& 5). The winter sample (19 February 2003, sample code: Ke0219) was dominated by eukaryotic plastids ( $79 \%$ of total clones). Most of them $(71 \%)$ showed moderate pairwise similarities (90.8 to $96.2 \%$ ) to trebouxiophyceaean green algae (to Auxenochlorella, Chlorella and Parachlorella sequences) and could be regarded as putative members of the Trebouxiophyceae, Chlorophyta (Fig. 5). These clones showed relatively high sequence divergence (minimum pairwise similarity $85.4 \%$ ). Conversely, no green algae were detected in the fall sample (26 October 2005, sample code: Ke1026). Minor components of the clone libraries were related to heterotrophic bacteria (9 and $2 \%$ of clones in the case of Ke0219 and Ke1026 clone libraries, respectively). 


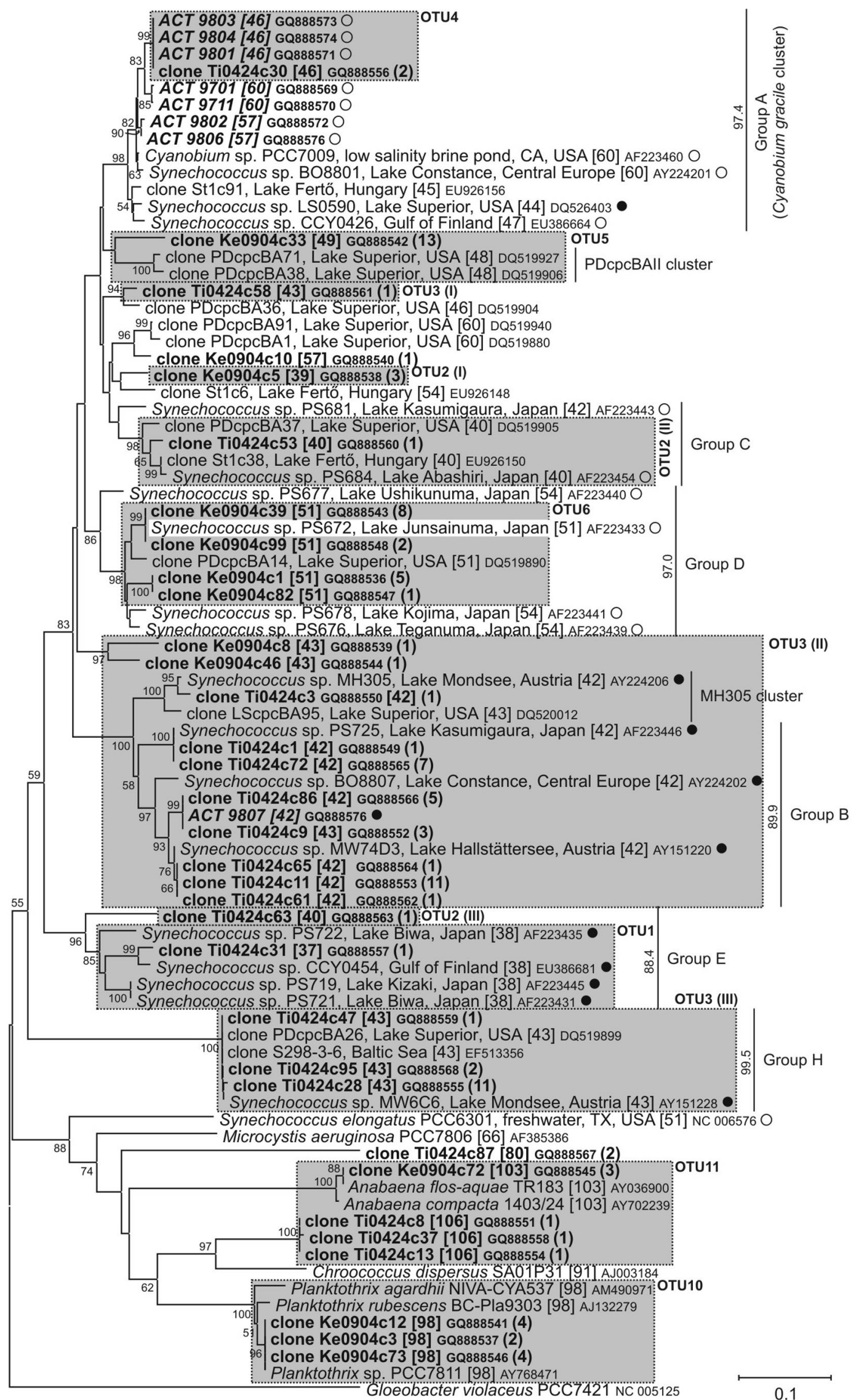


Fig. 4. Phylogenetic positions of picocyanobacterial isolates and $c p c B A$-IGS-derived clones from Lake Balaton (Hungary) within the Cyanobacteria. The neighbor-joining tree is based on 285 unambiguously aligned nucleotide positions. The length of the IGS region is given in square brackets for each sequence. Gray boxes indicate operational taxonomic units (OTUs) containing sequences from Lake Balaton with identical $c p c B A$-IGS length that were found in length polymorphism patterns (see also Fig. 2B). (Note that due to an extra amino acid in the $c p c B$ gene the length of the amplified region is 3 nucleotides longer in the case of Synechococcus sp. PS672 compared with other members in the same group; the amplified fragment of the $c p c B$ gene is also 3 nucleotides longer in the case of the Anabaena sequences.) Roman numerals after OTU numbers indicate that the corresponding OTU is split into different phylogenetic groups. @: phycoerythrin (PE)-rich, O: phycocyanin (PC)-rich. For other details see the legend of Fig. 2. Gloeobacter violaceus PCC7421 was used as outgroup

\section{Length heterogeneity analysis of the phycocyanin operon (cPcBA-IGS LH-PCR)}

Twelve OTUs were detected based on the length heterogeneity analysis of the $c p c B A$-IGS region (Fig. 2B). In the warm-water period of 2006, OTUs 1 to 10 were detected in the eastern basin, while in the western basin OTU 2, OTU 3, OTUs 5 to 7 and OTUs 10 to 12 were present. All the detected OTUs showed characteristic temporal variation in both basins of Lake Balaton (Fig. 2B).

Results of the analysis of the phycocyanin operon sequences (picocyanobacterial isolates and clones) were used to predict the phylogenetic position of the members of these OTUs. Because the primers we used may not be specific for all picocyanobacterial genotypes (design is based on previously known nucleotide sequences), and because sequences with a similar $c p c B A$-IGS amplicon length may be present in different phylogenetic groups, a strict OTU identification was performed. This means that sequence groups were assigned to LH-PCR OTUs only if they contained sequences (clones or isolates) from Lake Balaton. In this way, 6 OTUs (OTUs 1 to 6) were linked to different groups of picocyanobacteria on the phylogenetic tree (Fig. 4).

The $c p c B A$-IGS PCR protocol we used also amplified some genotypes related to larger cyanobacteria from Lake Balaton environmental samples (corresponding to 27 and $9 \%$ of the total number of clones in the case of the 2 clone libraries); 2 of these OTUs that have longer IGS (OTUs 10 and 11) were linked to Anabaena and Planktothrix sequences (Fig. 4).

The identification of OTUs could be improved by the construction of further срсBA-IGS-based clone libraries from Lake Balaton. It is possible that the iden- tified picocyanobacterial OTUs might contain other phylotypes, as is shown in Fig. 4, and some OTUs with longer IGS could also be linked to picocyanobacteria because some Synechococcus isolates are known to harbor IGS of even 100 bp (Robertson et al. 2001, Jasser et al. 2010).

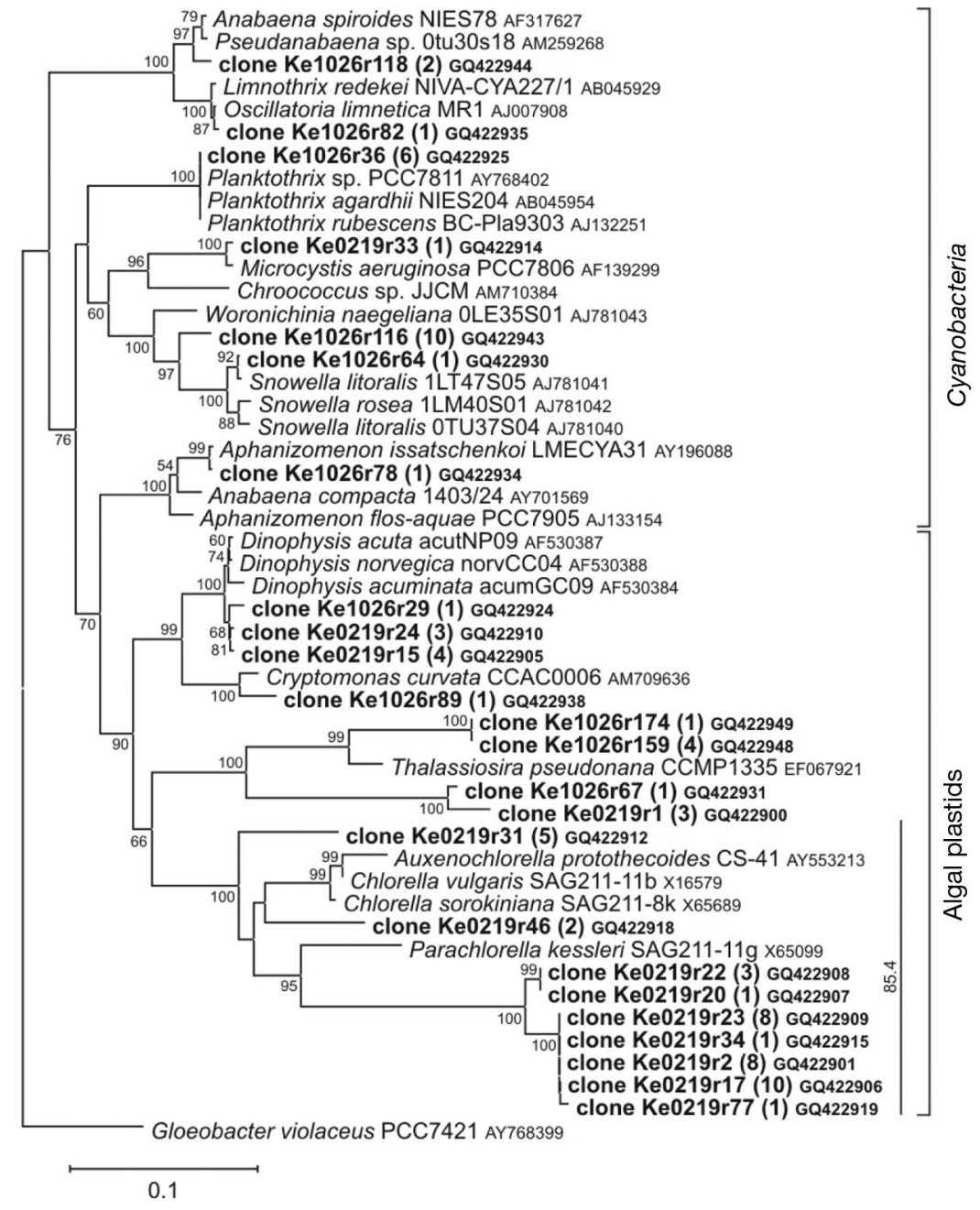

Fig. 5. Phylogenetic position of 16S rRNA-gene-derived clones from Lake Balaton (Hungary) outside the picophytoplankton clade of Cyanobacteria. The neighbor-joining tree is based on 561 unambiguously aligned nucleotide positions. For details see the legend of Fig. 2. Gloeobacter violaceus PCC7421 was used as outgroup 


\section{Correlation of individual LH-PCR genotypes with environmental variables}

Because the values of $\mathrm{pH}$ and conductivity varied only on a small scale in the warm-water period of 2006, these parameters were excluded from the correlation analysis. The vertical extinction coefficient $\left(\mathrm{K}_{\mathrm{d}}\right)$ could be significantly influenced by weather conditions (e.g. wind) and could change dramatically within a few hours in the shallow Lake Balaton; therefore, to link its actual value at sampling time with the results we obtained may result in misleading conclusions. The fourth parameter that was not included in the statistical analysis is the abundance of picoeukaryotic algae; the reason is that this group was detected in only a single sample with low abundance.

PCA was performed for the visualization of relationships among environmental variables and samples (Fig. 6), where the first 2 components accounted for a high percentage of total variation (PC 1: $46.0 \%$ and PC 2: $25.7 \%$ ). The 2 sampling sites were separated along PC 1 (except 1 sample from the western basin); the eutrophic western basin was coupled with a higher concentration of chl a, PC-rich picocyanobacteria and non-PPP cyanobacteria ('eutrophic' direction), while the mesotrophic eastern basin was characterized by higher concentrations of dissolved nitrogen forms and PE-rich picocyanobacteria (see also the corresponding values in Table 1). Temperature and the abundance of colonial and total picocyanobacteria were the main contributors for PC 2 with the same orientation ('warm' direction).

Several LH-PCR OTUs were significantly fitted as vectors onto the PCA ordination. OTUs with longer cpcBA-IGS amplicon size (OTUs 10 and 11, corresponding to Anabaena and Planktothrix in Fig. 4) were coupled with the 'eutrophic' direction of PC 1, while shorter OTUs (corresponding to picocyanobacterial sequences in Fig. 4.) were affiliated positively ('warm' direction, OTUs 2 and 6) or negatively (OTUs 3 and 7) with PC 2. Some of these relations between the environmental variables and OTUs had high correlation values, e.g. OTU 2 and temperature (0.7743) or OTU 3 and temperature (-0.7617) (Fig. 6).

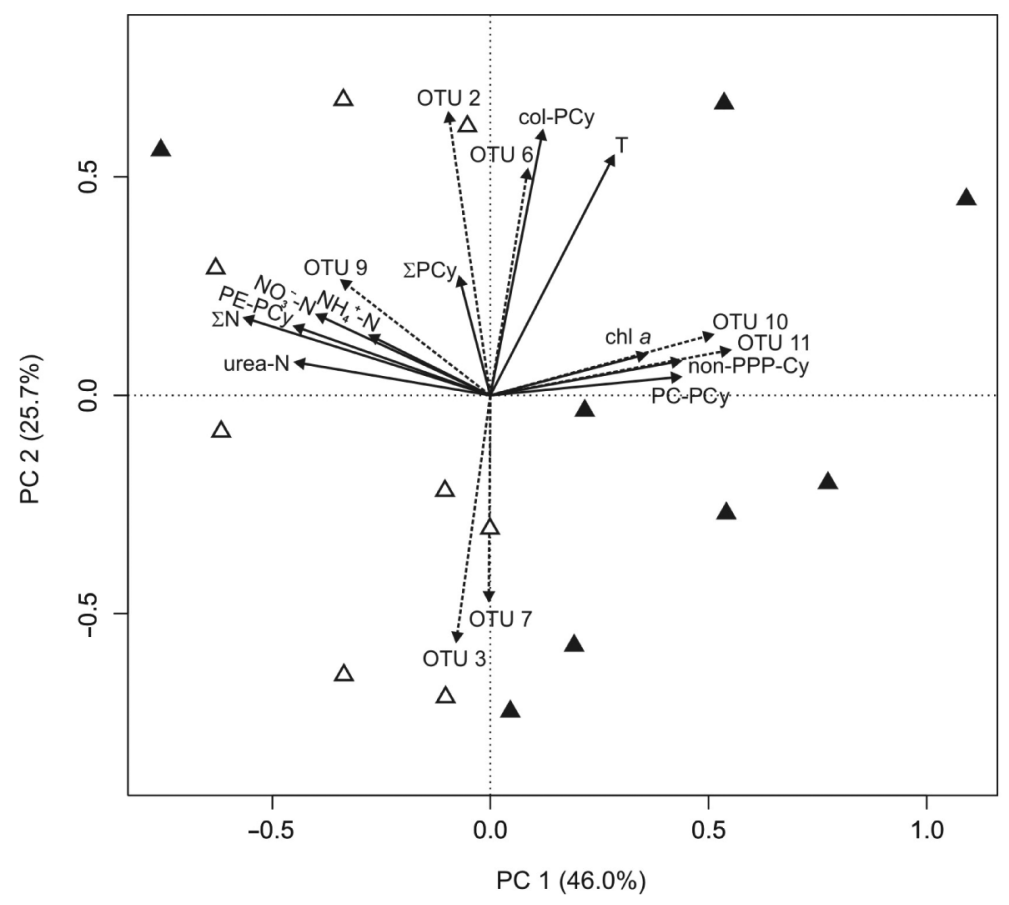

\begin{tabular}{|lc|}
\hline & \\
OTU 2 and temperature & $\mathbf{0 . 7 7 4 3}$ \\
OTU 2 and col-PCy & $\mathbf{0 . 7 9 0 2}$ \\
OTU 3 and temperature & $-\mathbf{0 . 7 6 1 7}$ \\
OTU 3 and col-PCy & -0.6779 \\
OTU 4 and PC-PCy & -0.5873 \\
OTU 4 and non-PPP-PCy & -0.5004 \\
OTU 5 and non-PPP-PCy & 0.5027 \\
OTU 6 and temperature & 0.6578 \\
OTU 6 and chl $a$ & 0.5022 \\
OTU 6 and col-PCy & 0.6805 \\
OTU 7 and temperature & -0.5665 \\
OTU 7 and col-PCy & -0.5915 \\
OTU 9 and NH ${ }_{4}{ }^{+}$- & 0.5189 \\
OTU 9 and NO${ }_{3}^{-}$- & 0.5046 \\
OTU 9 and PE-PCy & 0.6222 \\
OTU 9 and PC-PCy & $-\mathbf{0 . 7 4 0 2}$ \\
OTU 10 and chl $a$ & 0.6134 \\
OTU 10 and non-PPP-Cy & $\mathbf{0 . 8 3 1 4}{ }^{\star *}$ \\
OTU 11 and chl a & 0.6817 \\
OTU 11 and non-PPP-PCy & 0.6817 \\
OTU 11 and PE-PCy & -0.6644 \\
OTU 12 and PE-PCy & -0.5701 \\
\hline
\end{tabular}

Fig. 6. Relationships between environmental variables and length heterogeneity PCR (LH-PCR) operational taxonomic units (OTUs) in Lake Balaton (Hungary) during the warm-water period of 2006. Environmental variables are shown with arrows on the principal component analysis (PCA) ordination. Significantly fitted OTUs $(p<0.1)$ appear as arrows with broken lines. $\Delta$ : samples from the eastern basin (Siófok Basin); $\mathbf{\Delta}$ : samples from the western basin (Keszthely Basin). Correlations (Spearman) between OTUs and environmental variables $>0.5$ or $<-0.5$ are shown in the right-hand panel (correlations $>0.7$ or $<-0.7$ appear in bold; ${ }^{*} \mathrm{p}^{\prime}<0.05,{ }^{* *} \mathrm{p}^{\prime}<0.01$ ). For abbreviations see 'Materials and methods: Statistical analysis' 


\section{DISCUSSION}

\section{Composition and diversity of photoautotrophic picoplankton in Lake Balaton}

The majority of the observed phenomena relating to Lake Balaton PPP (e.g. picocyanobacterial abundance followed the changes in water temperature; the higher turbidity and trophic state of the western basin favored the dominance of PC-rich forms) were in accordance with the results of previous studies and were discussed in detail earlier (see Vörös et al. 1991, 1998, Mózes et al. 2006, Vörös et al. 2009). We found that the abundance of colonial picocyanobacteria was positively related to water temperature. Similarly, in the oligo-mesotrophic prealpine Lake Mondsee, Crosbie et al. (2003b) found that microcolonies of PPP occurred most frequently at nearsurface depths during periods of calm and sunny weather. They also concluded that the production of a photosynthate-rich mucilage 'may protect phytoplankton from photochemical damage by accommodating the rapidly produced biochemical reductants that are supplied by the light reactions of photosynthesis' (Crosbie et al. 2003b, p. 63). Another study (Jezberová \& Komárková 2007) showed that the aggregation of picocyanobacterial cells was the result of grazing pressure. Mózes et al. (2006) reported that the abundance of colonial forms increased with the decrease in the concentration of available nitrogen forms in Lake Balaton in the period 2003 to 2004, indicating the relationship between colony formation and nutrient limitation. Therefore, colony formation seems to be induced by several environmental factors, and the importance of these factors could vary from lake to lake, or could differ seasonally, or annually, even in the same lake.

Close relatives of larger colony-forming cyanobacterial genera, Microcystis and Snowella, were also detected with cloning and sequencing. These cyanobacteria possess cells corresponding to the widest sense of the picosize range $(<3 \mu \mathrm{m})$ (Rajaniemi-Wacklin et al. 2006, Willame et al. 2006). Among others, these cyanobacteria were also detected by microscopy and are well-known inhabitants of Lake Balaton (e.g. Présing et al. 2001).

Our molecular diversity analysis of PPP revealed more than 10 different picocyanobacterial groups of the picophytoplankton clade in Lake Balaton. Group A was represented by 7 PC-rich isolates, and this group also contained the only previously described PPP genotype from the lake, Synechococcus sp. BGS171 (Ernst et al. 2003). The sole PE-rich picocyanobacterium isolate was related to Group B, in which all previously reported culturable members have PE pigment-dominance (Crosbie et al. 2003a, Ivanikova et al. 2007). Clones of this group were found in both investigated basins of the lake, in accordance with the epifluorescence microscopy. Many other groups of the picophytoplankton clade were detected with cloning and sequencing, and some genotypes were related distantly to sequences available in GenBank (www.ncbi.nlm.nih.gov/genbank). However, several detected phylotypes were closely related to sequences retrieved from distant geographic locations and/or from aquatic habitats with different limnological characteristics; this supported the notion that these PPP types are widely dispersed and have a high potential for adaptation.

Picoeukaryotic algae are characteristically present in the whole lake during winter, spherical cells being the most common forms (Mózes et al. 2006, Vörös et al. 2009). Putative picoeukaryotic algal sequences formed 3 distinct phylogenetic groups, and the closest relatives of these clones were isolates belonging to the group Trebouxiophyceae (Chlorophyta) sharing moderate pairwise similarity values. Because the chloroplast 16S rRNA gene database of green algae is incomplete, the exact species composition of eukaryotic PPP in Lake Balaton remains unknown. Small, rod-shaped green algae (ca. $1 \mu \mathrm{m}$ wide, 4 to $6 \mu \mathrm{m}$ long), containing oil droplets, were also reported previously from the lake and were identified as Stichococcus minutissimus (Trebouxiophyceae) based on morphological investigations (Vörös et al. 2009). Additionally, analysis of winter planktonic samples from Lake Balaton with denaturing gradient gel electrophoresis (DGGE) resulted in the detection of Nannochloris bacillaris (Trebouxiophyceae) (98.9 and $100 \%$ pairwise similarity values based on the 18S rRNA gene; T. Felföldi, unpubl. results). Consequently, the eukaryotic PPP of Lake Balaton may also possess significant (and unexplored) genetic diversity, and trebouxiophyceaean green algae may be the characteristic members of the winter PPP.

\section{LH-PCR as a novel method for studying genetic diversity of freshwater picocyanobacterial communities}

In our study, the seasonal dynamics were followed by changes in the LH-PCR patterns of the picocyanobacterial community generated by amplification of the phycocyanin operon (which contains a noncoding region of variable size). The LH-PCR technique was applied previously in studies assessing the diversity of the microbial community in samples from various origins; the majority of these investigations focused on the length polymorphism of different regions of the ribosomal operon (16S rRNA gene or internal transcribed spacer [ITS]) (reviewed in Mills et al. 2007). One of the first studies (Suzuki et al. 1998), which targeted the 16S rRNA gene, dealt with the diversity of a marine picoplankton community, but 
according to our best knowledge, the study presented here is the first to apply this technique to the investigation of genetic diversity in PPP based on a region containing genes encoding an aspect of photosynthesis.

The identification of groups having similar amplicon length (environmental LH-PCR OTUs) was achieved by the parallel electrophoresis of PCR products from the phytoplankton community with PCR products from identified picocyanobacterial isolates; this was followed by a comparison of the in silico amplicon length of oxygenic phototrophic sequences retrieved from the same environment. With the sequence-aided LH-PCR protocol we used, a finer internal structure of picocyanobacteria was retrieved compared with the results obtained with commonly used techniques, such as epifluorescence microscopy. Even so, $c p c B A$-IGS-based LH-PCR underestimated the real picocyanobacterial diversity - as was indicated with the splitting of 2 OTUs (OTUs 2 and 3) in the phylogenetic tree. On the other hand, the protocol we used is simple, and it contains a relatively small number of steps (e.g. compared with sequence-aided terminal restriction fragment length polymorphism [T-RFLP], it lacks the requirement for restriction digestion of amplified genomic DNA; e.g. Székely et al. 2008, Felföldi et al. 2010). Because all stages in molecular biological approaches may introduce significant biases (Wintzingerode et al. 1997, Sipos et al. 2007), methods with fewer stages should have a less distorting effect on the original community structure. Another advantage of the LH-PCR approach (as with DGGE and cloning) is that it provides information about the whole community, contrary to quantitative PCR (applied in some freshwater studies dealing with picocyanobacterial seasonal dynamics; Becker et al. 2002, 2004, 2007, Sánchez-Baracaldo et al. 2008) or dot-blot hybridization (a frequently used technique in the genetic analysis of PPP in marine environments; e.g. Fuller et al. 2005, Zwirglmaier et al. 2008). Because the phycocyanin operon is not present in freshwater picoeukaryotic algae, only seasonal changes in the picocyanobacterial community could be observed with the $c p c B A$-IGS analysis. It should be noted that the specificity of the protocol we used can be further improved by excluding non-PPP genotypes (e.g. designing PCR primers that are more specific) or by performing size-fractionation prior to the molecular biological investigations. However, this latter option would result in the exclusion of colonial forms.

\section{Relationship of LH-PCR genotypes to environmental variables in Lake Balaton}

Statistical analysis revealed a robust separation between the 2 sampling sites, which was coupled with features related to trophic status: concentration of chl $a$ and nitrogen forms, abundance of PC-rich and PE-rich picocyanobacteria and non-PPP cyanobacteria. LH-PCR OTUs of larger cyanobacteria (Anabaena and Planktothrix) were characteristic of the eutrophic western basin, in accordance with observations by microscopy. The lower available nitrogen content in this basin resulted in the intensive biomass production of filamentous nitrogen-fixing cyanobacteria (A. aphanizomenoides, A. gracile, A. issatschenkoi, C. raciborskii). Additionally, these larger cyanobacteria outcompeted other algal groups (dinoflagellates, non-nitrogen-fixing cyanobacteria and diatoms) in summer (Présing et al. 2001, 2008), and their biomass changed inversely with that of the PPP (Vörös et al. 1991).

Nitrogen plays an important role in the annual cycle of the phytoplankton in Lake Balaton, and the concentration of available nitrogen may also determine the relative abundance of some picocyanobacterial genotypes. In our case, only a single genotype (OTU 9) correlated with the concentration of nitrogen forms, but unfortunately its phylogenetic position was not revealed due to the moderate number of analyzed clones ( $\sim 50$ to 60 ) that allowed only the identification of major cyanobacterial groups in the community.

Independently of the physicochemical and biological factors related to sampling sites and trophic status, temperature was the most important parameter that had a statistically relevant impact on the structure of the PPP community. Beside the above-mentioned features (abundance of total picocyanobacteria and colonial forms), the relative abundance of several picocyanobacterial genotypes also correlated positively or negatively with water temperature. OTU 3 was linked (among others) to Group B and correlated negatively with water temperature. In Lake Constance, genotype BO8807 of Group B showed its highest relative abundance during winter and spring in the upper $8 \mathrm{~m}$ of the pelagic zone (Becker et al. 2007) and was also abundant in the light-limited metalimnion/ hypolimnion $(0.2 \%$ of the surface irradiance). Other studies revealed that PE-rich isolates from Group B were more sensitive to photoinhibition than were PCrich picocyanobacterial strains from Groups A and I (Callieri et al. 2005, Moser et al. 2009). These results suggest that picocyanobacteria of Group B are adapted to cold temperatures and low-intensity light. The relative abundance of another LH-PCR genotype (OTU 7) was also coupled with low water temperature, but the phylogenetic identification was not possible due to its minor relative abundance and absence in the analyzed small clone libraries.

The relative abundance of 2 genotypes (OTUs 2 and 6) correlated positively with temperature, and these genotypes were affiliated with ecophysiologically undefined phylogenetic groups (Groups $\mathrm{C}$ and D) or 
ungrouped sequences; however, the positive correlation between these genotypes and the abundance of colonial picocyanobacteria suggests that colony-forming potential could be a characteristic feature of these groups.

In this study, only certain environmental variables were measured and coupled with the relative abundance of individual genotypes. The concentration of other nutrients (e.g. phosphorus, Becker et al. 2007) may also contribute to the internal dynamics of picocyanobacteria. The preference of certain cyanophages for infecting specific strains of picocyanobacteria was demonstrated earlier (Dillon \& Parry 2008), so that viral control could be another important factor affecting the ratio of various genotypes (Mühling et al. 2005). To reveal the role of other abiotic factors (e.g. wind, sediment resuspension) and biotic factors (e.g. grazing, interspecies relationships) on different picocyanobacterial genotypes in shallow lakes could be an interesting issue for the future.

\section{CONCLUSIONS}

A high diversity of picocyanobacterial genotypes, revealed by sequence analysis of isolates and environmental clones, was found in the large, shallow Lake Balaton. Some of the phylotypes we detected were only distant relatives of available database sequences from various aquatic environments. Several others represented close relatives of sequences retrieved from different aquatic ecosystems, supporting the notion that these groups are highly dispersive and have potential for adaptation. With the application of a novel method (length heterogeneity analysis of the phycocyanin operon), significant spatial and temporal differences were observed in the picocyanobacterial community. The relative importance of some of the genotypes we detected was coupled with environmental variables (temperature, available nitrogen forms). The results of this study highlight the fine internal structure and dynamics of the PPP community in freshwater ecosystems - a view that is usually blurred by the lower resolution of commonly used techniques such as epifluorescence microscopy and flow cytometry.

Acknowledgements. The contribution of E. Koncz and A. W. Kovács to the isolation, identification and maintenance of picocyanobacterial cultures is gratefully acknowledged. We thank J. Podani for helpful comments. This work was supported by the Hungarian Scientific Research Fund (OTKA K 73369). T.F. and B.V. were supported by a scholarship from the Ministry of Education and Culture, Hungary (DFÖ 0051/2009 and DFÖ 0054/2009).

\section{LITERATURE CITED}

Agawin NSR, Duarte CM, Agustí S (2000) Nutrient and temperature control of the contribution of picoplankton to phytoplankton biomass and production. Limnol Oceanogr 45:591-600

$>$ Becker S, Fahrbach M, Böger P, Ernst A (2002) Quantitative tracing, by Taq nuclease assays, of a Synechococcus ecotype in a highly diversified natural population. Appl Environ Microbiol 68:4486-4494

> Becker S, Singh AK, Postius C, Böger P, Ernst A (2004) Genetic diversity and distribution of periphytic Synechococcus spp. in biofilms and picoplankton of Lake Constance. FEMS Microbiol Ecol 49:181-190

Becker S, Richl P, Ernst A (2007) Seasonal and habitat-related distribution pattern of Synechocccus genotypes in Lake Constance. FEMS Microbiol Ecol 62:64-77

Bell T, Kalff L (2001) The contribution of picophytoplankton in marine and freshwater systems of different trophic status and depth. Limnol Oceanogr 46:1243-1248

Callieri C, Moro S, Caravati E, Crosbie ND, Weisse T (2005) Strain-specific photosynthetic response of freshwater picocyanobacteria. Verh Int Verein Limnol 29: $777-782$

Casamayor EO, Pedrós-Alió C, Muyzer G, Amann R (2002) Microheterogeneity in $16 \mathrm{~S}$ ribosomal DNA-defined bacterial populations from a stratified planktonic environment is related to temporal changes and to ecological adaptations. Appl Environ Microbiol 68:1706-1714

> Crosbie ND, Pöckl M, Weisse T (2003a) Dispersal and phylogenetic diversity of nonmarine picocyanobacteria, inferred from 16S rRNA gene and $c p c B A$-intergenic spacer sequence analyses. Appl Environ Microbiol 69: $5716-5721$

Crosbie ND, Teubner K, Weisse T (2003b) Flow-cytometric mapping provides novel insights into the seasonal and vertical distributions of freshwater autotrophic picoplankton. Aquat Microb Ecol 33:53-66

> Dillon A, Parry JD (2008) Characterization of temperate cyanophages active against phycocyanin-rich Synechococcus species. Freshw Biol 53:1253-1261

Ernst A, Becker S, Wollenzien UI, Postius C (2003) Ecosystemdependent adaptive radiations of picocyanobacteria inferred from 16S rRNA and ITS-1 sequence analysis. Microbiology 149:217-228

Felföldi T, Somogyi B, Márialigeti K, Vörös L (2009) Characterization of photoautotrophic picoplankton assemblages in turbid, alkaline lakes of the Carpathian Basin (Central Europe). J Limnol 68:385-395

Felföldi T, Székely AJ, Gorál R, Barkács K and others (2010) Polyphasic bacterial community analysis of an aerobic activated sludge removing phenols and thiocyanate from coke plant effluent. Bioresour Technol 101:3406-3414

Felföldi T, Somogyi B, Márialigeti K, Vörös L (2011) Notes on the biogeography of non-marine planktonic picocyanobacteria: re-evaluating novelty. J Plankton Res (in press) doi: 10.1093/plankt/FBR051

> Fuller NJ, West NJ, Marie D, Yallop M, Rivlin T, Post AF, Scanlan DJ (2005) Dynamics of community structure and phosphate status of picocyanobacterial populations in the Gulf of Aqaba, Red Sea. Limnol Oceanogr 50: 363-375

Hammer Ø, Harper DAT, Ryan PD (2001) PAST: Paleontological statistics software package for education and data analysis. Palaeontologia Electronica 4: article 4

Herodek S (1988) Limnology of Lake Balaton. In: Misley K 
(ed) Lake Balaton research and management. Nexus, Budapest, p 9-28.

Hillebrand H, Dürselen CD, Kirschtel D, Pollingher U, Zohary $\mathrm{T}$ (1999) Biovolume calculation for pelagic and benthic microalgae. J Phycol 35:403-424

Homonnay ZG, Kéki Z, Márialigeti K, Tóth EM (2011) Bacterial communities in the gut of the freshwater copepod Eudiaptomus gracilis. J Basic Microbiol (in press) doi:10. 1002/jobm.201100052

Ivanikova NV, Popels LC, McKay ML, Bullerjahn GS (2007) Lake Superior supports novel clusters of cyanobacterial picoplankton. Appl Environ Microbiol 73:4055-4065

> Jasser I, Karnkowska-Ishikawa A, Kozłowska E, Królicka A, Łukomska-Kowalczyk M (2010) Composition of picocyanobacteria community in the Great Mazurian Lakes: Isolation of phycoerythrin-rich and phycocyanin-rich ecotypes from the system - comparison of two methods. Pol J Microbiol 59:21-31

Jezberová J, Komárková J (2007) Morphological transformation in a freshwater Cyanobium sp. induced by grazers. Environ Microbiol 9:1858-1862

Lane DJ (1991) 16S/23S rRNA sequencing. In: Stackebrandt E, Goodfellow M (eds) Nucleic acid techniques in bacterial systematics. John Wiley, New York, NY, p 115-175

MacIsaac EA, Stockner JG (1993) Enumeration of phototrophic picoplankton by autofluorescence microscopy. In: Kemp PF, Sherr BF, Sherr EB, Cole JJ (eds) The handbook of methods in aquatic microbial ecology. CRC Press, Boca Raton, FL, p 187-197

> Mills DK, Entry JA, Gillevet PM, Mathee K (2007) Assessing microbial community diversity using amplicon length heterogeneity polymerase chain reaction. Soil Sci Soc Am J 71:572-578

Moser M, Callieri C, Weisse T (2009) Photosynthetic and growth response of freshwater picocyanobacteria are strain-specific and sensitive to photoacclimation. J Plankton Res 31:349-357

Mózes A, Présing M, Vörös L (2006) Seasonal dynamics of picocyanobacteria and picoeukaryotes in a large shallow lake (Lake Balaton, Hungary). Int Rev ges Hydrobiol 91:38-50

Mühling M, Fuller NJ, Millard A, Somerfield PJ and others (2005) Genetic diversity of marine Synechococcus and cooccurring cyanophage communities: evidence for viral control. Environ Microbiol 7:499-508

Nübel U, Garcia-Pichel F, Muyzer G (1997) PCR primers to amplify 16S rRNA genes from cyanobacteria. Appl Environ Microbiol 63:3327-3332

Oksanen J, Blanchet FG, Kindt R, Legendre P and others (2010) vegan: community ecology package. R package version 1.17-0, available at http://CRAN.R-project. org/package=vegan

Pick FR (1991) The abundance and composition of freshwater picocyanobacteria in relation to light penetration. Limnol Oceanogr 36:1457-1462

Présing M, Herodek S, Preston T, Vörös L (2001) Nitrogen uptake and the importance of internal nitrogen loading in Lake Balaton. Freshw Biol 46:125-139

Présing M, Preston T, Takátsy A, Spróber P and others (2008) Phytoplankton nitrogen demand and the significance of internal and external nitrogen sources in a large shallow lake (Lake Balaton, Hungary). Hydrobiologia 599:87-95

R Development Core Team (2010) R: a language and environment for statistical computing. R Foundation for Statistical Computing, Vienna. Available at http://www.R-project. org
Rajaniemi-Wacklin P, Rantala A, Mugnai MA, Turicchia S and others (2006) Correspondence between phylogeny and morphology of Snowella spp. and Woronichinia naegeliana, cyanobacteria commonly occurring in lakes. J Phycol 42:226-232

Rippka R, Deruelles J, Waterbury JB, Herdman M, Stanier RY (1979) Generic assignments, strain histories and properties of pure cultures of cyanobacteria. J Gen Microbiol 111:1-61

Robertson BR, Tezuka N, Watanabe MM (2001) Phylogenetic analyses of Synechococcus strains (cyanobacteria) using sequences of $16 \mathrm{~S}$ rDNA and part of the phycocyanin operon reveal multiple evolutionary lines and reflect phycobilin content. Int J Syst Evol Microbiol 51: 861-871

> Sánchez-Baracaldo P, Handley BA, Hayes PK (2008) Picocyanobacterial community structure of freshwater lakes and the Baltic Sea revealed by phylogenetic analyses and clade-specific quantitative PCR. Microbiology 154: 3347-3357

> Sipos R, Székely AJ, Palatinszky M, Révész S, Márialigeti K, Nikolausz M (2007) Effect of primer mismatch, annealing temperature and PCR cycle number on 16S rRNA genetargeting bacterial community analysis. FEMS Microbiol Ecol 60:341-350

Somogyi B, Felföldi T, Dinka M, Vörös L (2010) Periodic picophytoplankton predominance in a large, shallow alkaline lake (Lake Fertö/Neusiedlersee). Ann Limnol 46:9-19

Stomp M, Huisman J, Vörös L, Pick FR, Laamanen M, Haverkamp T, Stal LJ (2007) Colourful coexistence of red and green picocyanobacteria in lakes and seas. Ecol Lett 10:290-298

Suzuki M, Rappé MS, Giovannoni SJ (1998) Kinetic bias in estimates of coastal picoplankton community structure obtained by measurements of small-subunit rRNA gene PCR amplicon length heterogeneity. Appl Environ Microbiol 64:4522-4529

Székely AJ, Sipos R, Berta B, Vajna B, Hajdú C, Márialigeti K (2008) DGGE and T-RFLP analysis of bacterial succession during mushroom compost production and sequenceaided T-RFLP profile of mature compost. Microb Ecol 57:522-533

Tamura K, Dudley J, Nei M, Kumar S (2007) MEGA4: molecular evolutionary genetics analysis (MEGA) software version 4.0. Mol Biol Evol 24:1596-1599

Urbach E, Scanlan DJ, Distel DL, Waterbury JB, Chisholm SW (1998) Rapid diversification of marine picophytoplankton with dissimilar light-harvesting structures inferred from sequences of Prochlorococcus and Synechococcus (Cyanobacteria). J Mol Evol 46:188-201

Utermöhl H (1958) Zur Vervollkommnung der quantitativen Phytoplankton-Methodik. Mitt Int Ver Theor Angew Limnol 9:1-38

> Vajna B, Nagy A, Sajben E, Manczinger L and others (2010) Microbial community structure changes during oyster mushroom substrate preparation. Appl Microbiol Biotechnol 86:367-375

Vörös L (1991) Importance of picoplankton in Hungarian shallow lakes. Verh Int Ver Theor Angew Limnol 24: 984-988

Vörös L, Gulyás P, Németh J (1991) Occurrance, dynamics and production of picoplankton in Hungarian shallow lakes. Int Rev Ges Hydrobiol 76:617-629

Vörös L, Callieri C, Balogh KV, Bertoni R (1998) Freshwater picocyanobacteria along a trophic gradient and light quality range. Hydrobiologia 369/370:117-125 
Vörös L, Mózes A, Somogyi B (2009) A five-year study of autotrophic winter picoplankton in Lake Balaton, Hungary. Aquat Ecol 43:727-734

Wetzel RG, Likens GE (1991) Limnological analyses. Springer-Verlag, New York, NY

Wintzingerode F, Göbel UB, Stackebrandt E (1997) Determination of microbial diversity in environmental samples: pitfalls of PCR-based rRNA analysis. FEMS Microbiol Rev 21:213-229

Editorial responsibility: Rutger de Wit, Montpellier, France
Willame R, Boutte C, Grubisic S, Wilmotte A, Komárek J, Hoffmann L (2006) Morphological and molecular characterization of planktonic Cyanobacteria from Belgium and Luxembourg. J Phycol 42:1312-1332

Zwirglmaier K, Jardillier L, Ostrowski M, Mazard S and others (2008) Global phylogeography of marine Synechococcus and Prochlorococcus reveals a distrinct partitioning of lineages among oceanic biomes. Environ Microbiol 10:147-161

Submitted: June 7, 2010; Accepted: February 28, 2011 Proofs received from author(s): May 17, 2011 